Society and Economy 31 (2009) 2, pp. 271-293

DOI: $10.1556 /$ SocEc.31.2009.2.7

\title{
THE ROLE OF LAW AND ETHICS IN DEVELOPING BUSINESS MANAGEMENT AS A PROFESSION
}

\author{
DÁNIEL DEÁK \\ Full Professor, Corvinus University of Budapest, Research Fellow, \\ Taxation Law and Policy Research Institute, Monash University, Melbourne. \\ E-mail:daniel.deak@uni-corvinus.hu
}

Currently, business management is far from being recognised as a profession. This paper suggests that a professional spirit should be developed which could function as a filter of commercial reasoning. Broadly, management will not be organised within the framework of a well-established profession unless formal knowledge, licensing, professional autonomy and professional codes of conduct are developed sufficiently. In developing business management as a profession, law may play a key role. Where the idea is that business management should be more professionalised, managers must show that they are willing to adopt ethical values, while arriving at business decisions. The paper argues that ethics cannot survive without legal regulation, which, in turn, will not be supported by law unless lawyers can find alternative solutions to the large mechanisms of the official society, secured by the monopolised coercion of the nation state. From a micro perspective of law and business ethics, communities can be developed with their own conventions, rules and standards that are generated and sanctioned within the boundaries of the communities themselves.

Keywords: business management as a profession, formal knowledge, licensing, professional autonomy, professional codes of conduct, contents and nature of management activities, viable morality and its legal component, shortcomings of the state-centred and categorical generating and sanctioning of law

JEL codes: M14

\section{INTRODUCTION}

Business decisions have been strongly criticised in the recent years. Blind faith in narrow economic models, indifference to ethical issues, anomalies and manipulations in management have been explored. The suspicion has grown in leading business schools that something has gone wrong with the business school 
programmes. The idea has emerged that a framework should be developed for business decisions and management, in which business could be converted into a profession. This paper joins to the arguments in support of the need to professionalise the management of businesses. A special consideration is offered by the paper implying that the legal aspect of decision-making may help businesses corroborate in the process of professionalising business management.

\section{BUSINESS MANAGEMENT AS AN UNDER-PROFESSIONALISED OCCUPATION}

The management of businesses is an under-professionalised occupation today. Sociologists studying professions have employed a wide range of criteria for determining what makes an occupation a profession. Four criteria are extremely important in setting forth the essence of professionalism and comparing business management with the "bona fide" professions, such as law and medicine (Khurana - Nohria - Penrice 2005). These criteria are as follows:

(i) common body of knowledge resting on a well-developed, widely accepted theoretical base;

(ii) a system for certifying that individuals possess such knowledge before being licensed or otherwise admitted to practice;

(iii) commitment to applying specialised knowledge for the public good, and renunciation of the goal of profit maximisation, in return for professional autonomy and monopoly power; and

(iv) code of ethics, with provisions for monitoring individual compliance with the code and a system of sanctions for enforcing it.

The idea of management as a profession is plainly manifested in the proposed Hippocratic oath of managers (Khurana - Nohria 2008: 72-73).

Business management must not remain unregulated. Business activities must not be motivated merely by seeking for profit. They should be ennobled, and developed within the frames of a profession, or even a vocation. Louis Brandeis realised already in 1912 (Brandeis 1912) that the scope of recognised professions was being broadened (see in that respect, for example, the profession of engineers). Although we have been experiencing the time when capital is concentrated in the process of production, property is dispersed in terms of a large number of shareholders, and capital is built in the administrative system of the monopolised 
power of special knowledge, the process in which business management is converted into a profession has not yet been completed.

The formalisation of special skills and knowledge has not yet reached a level necessary for the creation of business management as a profession. The theory of corporate finance, for example, has already been developed, but this discipline has not been able sufficiently to reflect the requirements arising from the social environment of corporate functioning. While elaborating sophisticated methods of measuring risks, profits, costs and benefits, the theory of corporate finance has forgotten about the fact that business decisions cannot be made in a socially empty place, devoid of human deliberations that can hardly be directly converted into econometric formulae. The opportunity cost of decisions must be interpreted not only as a matter incurring financial costs. It is also important to understand that business decisions place on the participants of markets social burdens as well.

A profession can be located in a sphere where special knowledge is used, in the process of which those who pursue a profession leave the realm of mere egoism and cease to be bound to categories that can be measured according to the laws of the market only. Whether someone is successful depends not only on the fact if the decision-maker himself or herself is better off or not. It is also important that all parties involved in the bargain must be better off. It is superior to go beyond mere egoism than being bound to individual strategies, which is because building up personal connections and gaining better understanding of others can enhance the benefits of each social player.

Business management can become a profession, provided that at least two conditions are met:

(i) It is the substantive condition for the development of a profession that egoism must be superseded. This is the way in which it is possible to get the recognition of professional autonomy from the society.

(ii) It is the cognitive condition for the development of a profession that economics must be accompanied by the formalisation of managerial sciences at a level necessary for reaching professional standards.

The compensation paid for the professional performance must not directly depend on how successful the professional proxy was in the matter in which he or she assisted his or her principal. If such a direct link existed, the matter of reward would be exaggerated, although financial compensation for the professional work performed is in fact accidental to the assessment of this performance. The real success should be more durable and comprehensive than it could be expressed from time to time in terms of financial compensation. It is a matter of balance to be achieved between humans that cannot be merely subject to quantitative measure- 
ment, as what is reached is also a matter of agreement that cannot be simply expressed in monetary terms.

Indeed, in the business life profit is a principle of generating success by and large. One has to acknowledge as well that sustaining permanent losses is clearly a failure. Large profits, however, do not necessarily mean that one is successful. It is thus quite easy to describe if someone is successful in the business life in negative terms. Nevertheless, once it is required to use positive terms and suggest what it does mean to be successful, it is not enough to refer to the categories of profitability and efficiency. To be successful means a type of harmony one can achieve with others in particular social conditions. This is a kind of complexity that cannot be described simply by econometric categories. Brandeis (1912) contends that

\footnotetext{
“"Big business' will (...) mean business big not in bulk or power, but great in service and grand in manner. 'Big business' will mean professionalised business, as distinguished from the occupation of petty trafficking or mere moneymaking."
}

\section{HISTORIC MODELS FOR BUSINESS MANAGEMENT AS A PROFESSION}

It may be important not only to involve professional standards in business decisions, but also to try to benefit from the lesson to be drawn from the so-called liberal arts. The pursuit of the Seven Free Arts suggests more than mere professional recognition, as they negotiate originally universal values, not subject to necessities (Willmann 1907).

Becoming a professional suggests a possibility of leaving the world of mere pragmatism, because business decisions can be filtered, and mitigated by the rules reflecting a professional autonomy. A professional is still paying a fee. As a second step, even the world of professions could be left. Going beyond the professional barriers, it is possible to become a layman, as opposed to a professional who is now not bound longer to any professional consideration. In this way, the pursuit of a liberal profession suggests more than just following the rules of a profession. Instead, it is to rely on the universality of values that can be grasped within the framework of the Seven Free Arts. Approaching such universality cannot, however, take place without being complemented by spirituality.

In a modern society, professions mean independence, being present in the market of the services they supply. They make use of their specialised knowledge and are paid for the application of this knowledge to business matters. Due to their presence in the market economy, they are able to organise their services independently of systematic state intervention, still in competition with each other. On the 
contrary, in a pre-capitalist society, professionals are part of the historically determined systems of personal dependences that are organised by non-economic institutions like the state or the magistrates of guilds. Despite their subordination to non-economic factors, professionals are not necessarily precluded from exercising their vocation, while working as the masters of the work assigned to them. Necessity may be combined with the personal elevation of professional activities to the higher level of a vocation.

Professionals may always aspire to become the masters of their work. To do that, it is not enough for them just to establish financial independence. They also need spiritual and moral freedom, getting rid of the narrow-minded perspective of merely looking for profit. To that end, they must develop and preserve the inherent logic and integrity of their profession, no matter if they are successful as businessmen or women.

The historic patterns of the Western-type educated professionals are the intellectuals emerging in Europe in the Middle Ages. One of the early examples that may encourage modern professionals comes from the Cluniac movement. The monks of Cluny, and later a European-wide network of Benedictine monasteries, introduced new standards for the monastic life, consisting not only of the programme of spiritual and moral purification, but also of the idea that there could be different ways of approaching the only God. The reforms of Cluny operating in the $12^{\text {th }}$ century were completed by the autonomy movements of local communities, organised in the $13^{\text {th }}$ century against the feudal lords. City states of Northern Italy and Germany were developed as the islands of freedom in the sea of feudalism ("die städtische Luft macht frei"). The city life suggested a matter of locality, compared to the comprehensive territorial jurisdiction of the feudal lords. The enhancement of the logic of locality in organising professional life was helpful in avoiding the alienation effect of higher powers and developing mutual insights and the respect of one's neighbour. Thus, the supply of professional services required personal performance and devotion, underlying the technicalities of carrying on professional activities.

The city provided room for the universities founded already in $13^{\text {th }}$ century. Their staff was recruited from the clerical intellectuals, being simultaneously engaged in teaching and doing research. In fact, they were widely subject to professional regulations. They were, for example, obliged to respect the different rules of conducting discussions on different matters. On the other hand, they benefited from their privileges to obtain independence they found in the shadow of the permanent conflicts, which were prevalent between feudal lords and the Catholic Church. Being clericals, they were, by definition, approximate to spirituality. At the same time, they represented a link to the created world by developing profes- 
sional rules. One can admire the harmony they could form between spirituality and the immanent world.

The clerical intellectuals were not far from the group of the "jongleurs" who were also successful in seceding from the official hierarchies of the feudal society. While maintaining their roots to spirituality, they were integral parts of the every-day life. They enjoyed freedom paradoxically due to the fact that they appeared in the guise of clowns and, as such, they were not recognised as full members of the official society.

One of the famous examples for the scene of their presence is the "Roman de la Rose", ascribed to Guillaume de Lorris and Jean de Meun, a work of the early $15^{\text {th }}$ century, providing the combination of allegories and high sensuality even up to eroticism. The puzzling mixture of spirituality and physical desires is exemplified in the triptych of Melun as well. In this painting, Jean Fouquet shows the model of chastity and devotion, appearing in the person of Virgin Mary. In the portrait of the Madonna, one can recognise, however, Agnes Sorel, a mistress of King Charles VII, suggesting another source of attraction as well.

A businessman engaged in bargaining is a man with instincts and emotions who arrives at good judgments, whose position is thus comparable to the character of an artist. From this perspective, the model of jongleurs is available. They need not be only the men of judgments, but may also have developed intimate relationship with the higher values of loyalty, honesty and human dignity (as we know good examples for that from Francois Villon). It is a point of orientation for businessmen as professionals as well to try to go beyond the border of simple bargaining and substantiate their business with deeper understanding and moral considerations.

Modern professionals can learn both from clerical intellectuals and jongleurs. They have to appreciate that the freedom these ancestors acquired was used in order to create works that could reflect a complete picture of life, including both immanent and transcendent values. Of course, not only positive, but also negative models exist. For example, it may be welcome to simulate an artist like Walter of Stolzing, a hero of Richard Wagner in the opera of "Meistersinger", who cannot get rid of a negative alter ego, represented by Beckmesser. People like Beckmesser may flout the professional rules, desperately missing the complexity of life.

It is another important source of erudition for modern professionals to benefit from the rational way of thinking that has been developed at the point of shifting from Platonic idealism to Aristotelian rationality. The economy of the production and exchange of commodities reached a level of development in the $13^{\text {th }}$ century when it was no longer possible to reconcile the poetic form of idealism inherited from the Neo-Platonic and Patristic tradition with the emerging realities of a market economy. The space for physical life and business was extended dramatically. 
It was then necessary to combine the Christian faith with the experience of the new way of life. Thomas Aquinas and his comrades rediscovered Aristotle and benefited from the balance, introduced in his works, between transcendent and immanent values. Aristotle had the idea that the substance of things is hidden in the things themselves, which can be explored, provided that affection, reason and experience are mobilised and brought into harmony with each other. In this way, beliefs fell under the control of logic and experience. In fact, there should be a link even for modern professionals between spiritual values and the rapid developments of material life.

It is crucial for professionals to rely on rationality, or, rather, instrumental rationality. Rationality, however, must not be separated from humility. One must see that there are constraints on cognition and social design. The European way of rational thinking has traditionally emerged from coping with the question of Job raised in the Middle Ages concerning the consequences of the commitment of sins. From a Gnostic perspective, good and evil can be distinguished from each other on the grounds that salvation cannot be reached and purity and chastity cannot be preserved unless everything that belongs to the physical world is absent from our life. Souls cannot be saved unless they are departed from the body. This kind of Docetism cannot be reconciled with the physical experience of our modern life. Even the Catholic Church has found it as heretic that the intercourse with what is corporeal would absolutely lead to vices.

The campaign against the Cathar heresy was introduced by the Mendicant fathers in the $13^{\text {th }}$ century. The Franciscan answer to the question concerning the relationship between the commitment of sins and the physical world was that this world created by God was brave and the Christians are invited to admire and enjoy the ample gifts of this world. They have to show, however, affection to the creatures of this world, in particular, they have to show compassion with those who are needy. The Dominicans successfully proved that the reason given by God could be brought into harmony both with affections and senses. Francesco of Assisi discovered in his "Cantico di frate sole" the beauties of nature surrounding our life and suggested that by way of entertaining affection, it was possible to get into an intimate relationship with the objects of nature. Furthermore, Thomas Aquinas was eminent in finding a language in his poem "Pange lingua gloriosi corporis mysterium", in which reason and religious faith could complement each other in an amazing harmony.

The metaphors introduced in these poems can be encouraging for intellectuals even today and can help professionals in not losing themselves to the mere problems of narrow-minded rationality, ideologies and the motivation of seeking profit. The miracles of nature can be explored by the professionals who may in- 
voke the spirit of Saint Francis, while the beauties of reasoning, as shown by Saint Thomas, can also be helpful to the professionals of our time.

Since Bernard of Chartres, it is known that intellectuals cannot survive without their ancestors. One can thus be potent in solving current problems just because of "standing on the shoulders of giants". Indeed, no profession can be pursued successfully unless professional methods are put in the context of the professional spirit that can arise from traditions. Professional problems must not be reduced to technicalities. Real answers cannot be given to real-life problems unless a professional takes the historical context into account. Traditions of course show us various of trends that must be observed, but at the same time they also reveal freedom. This is because a professional may choose the components of the relevant tradition that can be useful in solving the current problem.

\section{GOING BEYOND INSTRUMENTAL RATIONALITY}

A profession, representing more than simply carrying on commercial activities, implies a double nature that consists of both instrumental rationality and a way of thinking open to transcendent values. Upon the assessment of the possibility of conversion from the simple business management into profession, it is important to criticise instrumental rationality. Sumantra Ghoshal describes it by the overestimated use of explanation based on causal effects, by conducting research while getting lost in the details and by the destructive mentality driven by mistrust and the blind faith in seeking for the mere financial interests (Ghoshal 2005: 76). It is pure negativity just to seek to take cognisance of bounded rationality and the possible reduction of costs. It is then naive just to believe that there are exact scientific methods in doing in-depth analysis of the right economic conduct.

Clearly, the insufficiencies of the laws of the market cannot be adjusted by the never-existing brave prince who, being omnipotent, would be able to fix correct prices. It is also an illusion, on the other hand, to think that markets would produce perfection, or that the establishment of a market economy would be a natural form of the economic conduct. The economic conduct, related to instrumental rationality and followed in correspondence with the laws of the market, is constrained due to the fact that market players are inclined to disregard the considerations of others. This inadvertently leads market players to opportunism. While defending against opportunism, they show fears that others may prevent them from their full satisfaction, and thus operate in isolation from one another, which is a sort of one-sidedness, an inevitable constraint on better performance.

The operation of markets is overshadowed by imperfections due to the following factors at least: (i) historically, the economic conduct is institutionalised and 
imbedded into non-economic factors; (ii) the logic of the market exchange is always complemented by the logic of the autarchy of simple households; and (iii) instrumental rationality is not free from insufficiencies like egoism, negativism and personal biases.

Economists must not think of being omniscient. They must take care of the limits on the truth value of the cause and effect relationship. It is only this broader perspective, from which it is possible to understand why David, the great king of Juda and Israel, repented of organising a plebiscite, of an action to be preserved for God (2 Samuel, 24, 10). In the same way, it is only "the remnant of Israel", placing its hope into God, that can survive (Zephaniah, 3, 11-13). Without modesty and the awareness of the limits on the human conduct, it is easy to stray from the right way. A good example for that modesty can be found by looking at the issue of ecology-oriented policies.

According to Martin Buber, causality must be complemented by spirituality (the relationship of "I - It" must be complemented by that of "I - Thou"). Otherwise, people will miss even the standards of "moralia minima". Spiritual values are hidden in the language, or rather in the process of communication, which is because spiritual values are not given in advance. Instead, they are revealed in dialogues (Buber 1995: 3, 31, 33).

Those who are not aware of the organised complexity appearing in a society are able to practice only the pretence of sciences. There are strict limits on the knowledge about society and on the institutional interference of the state with social processes, Hayek argues (Hayek 1974). He contends that

"The recognition of the insuperable limits to his knowledge ought indeed to teach the student of society a lesson of humility which should guard him against becoming an accomplice in men's fatal striving to control society - a striving which makes him not only a tyrant over his fellows, but which may well make him the destroyer of a civilization which no brain has designed but which has grown from the free efforts of millions of individuals."

\section{PROFESSIONAL AUTONOMY}

From a sociological perspective, occupation means the pursuit of a profession, that is, integration into bureaucratically organised social mechanisms (Kasher 2005: 67). Being a member of a profession means independence in the Western part of the world after the French revolution, that is, liberation from the hierarchies of feudalism. While being regulated, a modern profession disposes with the strict rules of guilds that precluded competition.

Professional activity is part of the professional practice which is presupposed by systematic regulation. The major components of the professional practice are 
relevant knowledge, competence in problem solving and understanding the social environment of a profession and the professional spirit. Normally, the rules of a profession do not come from the outside world, but they are the product of practicing the profession itself. A profession cannot be recognised by what a professional does, but rather by the way in which a professional takes part in the practice of his or her profession (Kasher 2005: 73-75).

A profession is constrained by its own rules, but it also enjoys autonomy in determining how its representatives subject themselves to those rules and how they interpret the profession itself. There has been a dense net of professional rules by which individual autonomies are constrained within the profession. Following the rules of a profession means limits indeed. These rules, however, cannot be considered as instructions, instead, they are standards that are the posts of guidance rather than strict regulations. Being part of a profession means boundaries, while it also suggests an elbowroom for its members who establish their career independently (Kasher 2005: 94).

Knowledge and sciences are described by Talcott Parsons in terms of a system of institutionalised professional roles. Following Parsons, Eliot Freidson asserts that a profession is the carrier of the relevant knowledge that has been developed in a society (Freidson 1986: 685). Role-specific knowledge can be categorised as general, special and formal. Knowledge can be ascertained not only as the body of professions, but it can also be considered as a means of enforcing the claims for acquiring social positions. Professions are, in other words, the institutionalised instruments of formal knowledge, which suggests more than special or even specialised knowledge. It is a barrier to the profession's integrity. The professional spirit can be identified through the acknowledgment of formal knowledge, relevant to a particular profession. A profession is more than simply an occupation, because, in addition to practitioners, one can find university professors as well who supervise the process of producing formal knowledge. Even professional knowledge can be depreciated down to the level of applied knowledge, which is why only the academics and scholars possess the pure knowledge relevant to the profession (Freidson 1986: 689-690).

The pursuit of a profession must be put in a social context, so that none remains simply a matter of technical rationality, or a positivist epistemology of practice. An alternative for the mere use by professionals of technical rationality is the reflective one. Reflection goes beyond what is routine and rigour in the practitioner's everyday life, suggesting orientation towards what is relevant to the social environment, towards the praxis of a profession and towards the personal commitments of practitioners. The reflective rationality of practitioners consists of the moments of "refection-in-action" and "reflection-on-action". Donald Schön explains that the moment of the "reflection-in-action" can be interpreted as "think- 
ing on our feet", meaning the exploration and interpretation of the personal past. He writes (Schön 1983: 68):

\footnotetext{
"The practitioner allows himself to experience surprise, puzzlement, or confusion in a situation which he finds uncertain or unique. He reflects on the phenomenon before him, and on the prior understandings which have been implicit in his behaviour. He carries out an experiment which serves to generate both a new understanding of the phenomenon and a change in the situation."
}

The exercise of "reflection-on-action" presupposes, in turn, an encounter through which a practitioner can take a look at the world, using a repertoire of reflections (Schön 1983: 138):

\footnotetext{
"When a practitioner makes sense of a situation he perceives to be unique, he sees it as something already present in his repertoire. To see this site as that one is not to subsume the first under a familiar category or rule. It is, rather, to see the unfamiliar, unique situation as both similar to and different from the familiar one, without at first being able to say similar or different with respect to what. The familiar situation functions as a precedent, or a metaphor, or (...) an exemplar for the unfamiliar one."
}

Freidson describes the status of an academic by being engaged in teaching and doing research, which two roles are inseparable from each other. Research can hardly give existential independence, as there are no clients from whom it would be possible to earn. The publication of papers gives, however, prestige and the possibility to exercise influence on the whole profession. Professors earn regularly and have clients, that is, the students, but, they do not enjoy as much prestige as scholars (Freidson 1986: 692). One can add to the observations of Freidson that in the academia the historical model of clerical intellectuals has been valid to date who teach and do research at the same time, and who can do that because, being under the auspices of the (Catholic) Church, enjoy freedom from feudal powers.

Importantly, a profession can be described not only by the roles to be filled by the members of the profession, but also by the interests they have in obtaining various positions in professional organisations, and by the identity to be developed in relation to the position held. From a perspective of functionalism, a profession means the creation and dissemination through professional roles of formal knowledge, and, from a perspective of organisational positions, the identity authentically represented by the competent professional bodies (Freidson 1986: 698).

\section{BUSINESS MANAGEMENT AND "BONA FIDE" PROFESSIONS}

For the time being, a business manager is somewhat different from the representative of a bona fide profession. To repeat, the criteria of a bona fide profession are: 
formal knowledge, license, professional autonomy and the standards of ethical codes. Looking at the contents of the activities that are covered by the academic master programme of business administration, two major fields of proficiency can be distinguished: economic advising and management. The former can be compared to the normal professions of lawyers, doctors and the like. The latter is of rudimentary nature for the purposes of designing a well-regulated profession. The contents of managerial activities can be approximated by the term of POSDCORB (Planning, Organising, Staffing, Directing, Coordinating, Reporting and Budgeting), introduced by Luther Gulick (1937). For the students of business administration, professional standards may consist of the patterns of managers.

The regulation of professions may be diverse, depending on the culture in which they are pursued. Although the legal profession is one of the oldest ones, no uniform regulation has been developed. In some jurisdictions, two different professions can be identified within the regulated profession of lawyers: barristers and solicitors. The members of the former profession, being part of the judiciary system, are traditionally not allowed directly to get contacted by clients. Instead, they are hired by the solicitors to express their professional opinion and represent the solicitor's client before the courts. Solicitors are close to business advisors, assisting their clients in business planning, focusing on the legal side of the complex matters of business. For economic advisors as the representatives of a would-be profession, the model of solicitors can be a good pattern to follow, as much as the profession-in-formation of economic advisors could, in turn, serve as an ideal for the managers of businesses.

The basic components of a profile of the profession of business management can be summarised as follows:

- A key to developing particular formal knowledge is the study of theoretical and applied economics and the theory of administration. The relationship between economics and the theory of administration is still not clear. It is even doubtful if the study of administration is of scientific competence, although the disciplines of both public and business administration are of high importance in practice.

- The current system of licensing must be dramatically improved. Releasing a master's degree is not enough, as it must be complemented by a professional exam, following a period of time spent in service. A model for that can be the professional exam of lawyers that can be taken following a practice of about three years (an example for this is the system of the so-called "zweites Staatsexamen" in Germany). It is still doubtful if the current professional profile of managers suits the requirement of a professional exam to be taken following the university degree. Still, managers should be expected to meet a set 
of standards, close to fiduciary duties. The study of corporate governance could also be useful while designing appropriate standards.

- The development of professional autonomy is crucial, which serves mainly as a shield for managers against being unethical. The professional rules arising from this spirit may function as a filter of commercial reasoning in the everyday life of the professional practice. The spirit of profession obviously negotiates a corporate spirit. Accordingly, disciplinary measures can be introduced, so that functional differentiation arises, which takes place first by way of self-reflection. It suggests a process of coordination, in which the recursively determined forms of social cooperation can be developed. At the same time, the appropriate forms of actions will be selected by way of providing the observation of the relevant social background. A profession must thus not dispense with functional differentiation by developing the intrinsic nature of the given profession, or by following a way in which the members of a particular profession can determine their relationship to the outward business community.

- The development of ethical codes is vital, but they must not interfere with the autonomy of the profession's members. They can rather represent the standards that can be built in the ordinary practice. It is important not only to create an ethical code, but also to organise the forum at which the implementation of the ethical rules can be discussed. These rules can be filled up by life in the process of the interpretation only. If the different interpretations conflict with each other, it must be solved with a view to the respect of the profession's integrity.

\section{ETHICS AND INTEGRITY IN THE PROFESSION OF LAWYERS}

Lawyers (advocates in Europe, attorneys-at-law in America) are widely expected to contribute to the consolidation of the legal system in which they work. In most European jurisdictions, the legal profession falls within the scope of comprehensive and categorical legal regulation. It is yet less subject to the aspects of morality, although the attorney-client relationship cannot be interpreted without taking ethical requirements into consideration. These issues can be explained in brief as follows:

- Loyalty to the client requires the furtherance of the client matters. Indeed, the client can certainly expect that his or her attorney will assist him or her in enforcing his or her rights. It is the lawyer's duty at the same time to help the client with getting in compliance with the law, which may raise difficulties where the service of clients is in conflict with the requirement of legal compliance. 
- A lawyer is required to be impartial and serve as the actor of negotiating the ideas of mutual understanding, reconciliation, and peaceful solutions. A lawyer, in other words, is expected to act in the public interest, while contributing to the resolution of disputes.

- The establishment of personal integrity and good reputation requires that lawyers must be intact from the conflict of interests, so that they cannot be compromised by the intervention in illegal or suspicious transactions. It can also be considered as unethical for lawyers to limit or exclude their professional liability.

- Lawyers cannot act successfully unless their work is protected by privileged communication. It is in the public interest that clients be provided with the possibility of getting intimate advice if necessary. Keeping the client matters confidentially, however, does not mean to conceal vices. Lawyers, in addition, must strengthen public confidence by preparing documents professionally.

- In most jurisdictions, lawyers are prohibited from stipulating or accepting commission fees that would threaten professional independence. Hence, "pactum de quota litis" is usually prohibited, that is, the lawyer must not have any share in the result of the client's matters.

- The entitlement to personal publicity cannot be challenged, but certain limits must be maintained on advertising. In general, lawyers need defence against disruptive competition.

In common law countries, the lawyer's profession is traditionally bound to very high ethical standards. It is strongly emphasised there that lawyers must assist in maintaining the integrity and competence of their profession. It is also widely discussed how much the differences in the financial ability influence the capacity to make legal counsel. Indeed, professional competence can be prejudiced where the market of legal services is highly concentrated and clients cannot get access to good and cheap legal services.

In common law systems, much emphasis is put on the lawyer's duty to contribute to strengthening the integrity of the legal system, as it is less significant than on the European continent to deal with statutory law provisions. Under common law, legal cases must frequently be assessed, based on the very principles of law. For instance, it is important to take the principles of equity, due process, fair trial or the true and fair view of company books into account. They are not disregarded on the European continent either, but there is not as much elbowroom for their application, because it is the legislator's ambition to fill the gaps left by comprehensive and detailed statutory law regulation, sometimes even by government decrees. 
In Europe, legality means to defend citizens from the illegal use of the discretionary power of the public authorities, or to assist citizens in enforcing their subjective rights. Since the public authorities must not interfere with private matters, it must be discussed how this maxim can be observed in specific cases. In common law systems, there is no strict dividing line between the spheres of public and private life, because public duties are eventually traced back to private mandates. The public authorities can be widely sued and required to pay compensation for the damages caused in specific cases or by way of legislation. In Europe, the responsibility of the public authorities is a taboo in many cases. Namely, the actions of the public authorities cannot be discussed, only within the strict limits of public law cases.

In common law systems, the public administration is expected to operate in accordance with the principle of due process (a principle of natural justice or fairness), which is a procedural guarantee for the legality in the operation of public administration. As the principle of due process means the higher criterion of legality, according to which the administrative procedure can be assessed with regard to the protection of individual rights, there is no existing statutory law by which it would be preceded. Where this principle is applied in a civil law system, it can be problematic that one has to encounter the existing statutory law provisions, which are not necessarily in accordance with the conclusion that can be made as a result of the application of the due process principle.

As a consequence of the strong tradition of protecting privacy, ordinary people are open to apply, in common law jurisdictions, ethical, or even spiritual values to the solution of their problems. Ethical considerations are not far from the real life in civil law countries either. Their application is still not directly left for citizens; instead, they are typically organised by public institutions, which do not hesitate to interfere with the spheres of life, which are usually intact from state intervention in common law systems.

A good example for this is the treatment of companies. In the Anglo-Saxon world, they are normally expected purely to maximise the shareholder value, as the considerations of the social provision are far from the sphere of company management. The European approach is different due to the strong tradition of the participation rights of the workers ("droit de participation", "Mitbestimmungsrecht"). This is the reason why it took for more than three decades in the EU to agree on the concept of a harmonised European company statute (now adopted by Council Regulation 2157/01/EC on the European company statute in the form of "Societas Eurepaea").

Ethical issues are systematically raised on both sides of the English channel. Outside the European continent, the respect of ethical and human values is mainly established on individual decisions. The European tradition suggests, however, 
more emphasis on public institutions. In addition, in Europe social institutions are clearly separated from each other. Law is maintained in a nation state as an independent system, not subject to the values of the religious faith or moralities that arise from outside and above. There is a strong tradition of legal positivism, the core values of which are the centralised power of the state and the institutionalised monopolies of applying sanctions, strictly based on legal rules, and excluding non-legal considerations. Under such circumstances, the legal profession is less open to ethical considerations in Europe than in common law jurisdictions.

In the European Union, nation states have been invited to give up part of their sovereignty. In the early years, it was the idea in the European Communities that the European authorities had to simulate the conduct of the nation state as much as possible. Many efforts were therefore taken, for example, to introduce comprehensive Community legislation. Later, more stress has been laid on the subsidiarity principle. To date, substantive harmonisation has been replaced in many instances by the idea of the better coordination between the Member States, along with the efforts to reinforce the effective legal protection and the easy enforcement of the rights of citizens.

Disparities in national law may bring obstacles in the way of a smooth operation of the internal market. The question of the development of Community Law cannot still be confined to that of simple statutory harmonisation, which has been obvious since two decades at least when the state-centred, categorical, comprehensive and detailed statutory harmonisation was replaced by the more relaxed forms of the co-ordination of Member States in Community Legislation. Even more emphasis was placed on the self-regulation of professions acknowledged subsequently by various bodies of the Community. In this way, bottom up initiatives, arising from the negotiation of legitimate interests and the enforcement of individual rights, have contributed to the development of an additional source of harmonising Community Law. The question of the easy enforcement of rights has come to the forefront, and good answers can hardly be expected to arise from the traditional forms of statutory and positive harmonisation. This approach may obviously open avenues to the implementation of ethical values in the treatment of legal problems.

Being part of the judiciary system, the profession of lawyers is strictly subject to disciplinary measures. It can be interesting to take a short look at the European scene. One can realise that the freedom of establishment and services across the border of the European Community may get in conflict with the professional standards of lawyers that are regulated by the Member States. It is crucial to see at which point the EC freedoms must be enforced, what are the instances where professional integrity and autonomy must be respected, and the exercise of EC freedoms must be halted. ${ }^{1}$ 
It has turned out already in the Reyners case that even though the work of lawyers is part of the judiciary system, it does not mean that a lawyer would exercise public power. Consequently, he or she cannot be prevented on that ground from exercising the freedom of establishment across the border and start practicing as a lawyer of a certain Member State in another Member State. It has been clear however, from the early time that the freedom of establishment may be restricted by the intervention of a Member State for a number of reasons. It is not only the disparity in the use of languages or legal cultures that forms an obstacle in exercising the EC freedoms. There are standards arising from the professional integrity as well (conflict of interest, limits on advertising, mandatory professional training, etc.) that are to be enforced by the bar associations or other competent authorities operating in the Member States.

It comes from the Gullung case that the freedom of establishment can be restricted in the sense that even a foreign lawyer starting practice in the host Member State can be subject to the disciplinary measures of the host Member State, parallel to being subject to the disciplinary measures of the home Member State. In other words, a license released in the home Member State is not sufficient, despite the home licensing system introduced in the internal market for financial enterprises. This is because the activity of a guest lawyer could not be subject to professional supervision without being subject to the disciplinary measures of the host Member State.

Localisation is an important requirement that must be enforced with lawyers, meaning that a lawyer must not have offices at more than one place. Nevertheless, if this rule was applied mechanically, it would make an insurmountable obstacle in the way of exercising the freedom of establishment. This is why the EC Court requested in the Klopp case a host Member State to allow a guest lawyer to open an office there, even if the lawyer had had an office in the home Member State. The admittance will not cause disorder in respect of the national professional standards, because it is known that this lawyer is a guest in that country, not holding a status identical to that of domestic lawyers. Therefore, one has to take into account that the positions held by lawyers coming from different Member States are not comparable to each other in all cases.

One can conclude from this treatment that the operation of the lawyers' market cannot be understood without taking into account the professional standards that inadvertently constitute an obstacle from time to time to the freedom of economic competition, which is otherwise the basic rule within the European Community. It comes from the Wouters case that although a bar association cannot be released from being subject to the rules of free competition in general, it must be accepted that certain rules of bar will be issued, even if they restrict the exercise of EC freedoms, with a view to supporting the professional integrity of lawyers. This clearly 
opens a door for the assessment of the lawyer's work even from an ethical perspective. It has been spelled out in this case that a national bar may prevent a domestic lawyer from being merged within one unit of business organisation with other professions (in the specific case, with chartered accountants), which is because a lawyer must preserve his independence in order to be free from biases that would arise from the conflicts of interest.

\section{BUSINESS DECISIONS, ETHICS AND LAW}

It is a key in developing the master programmes of business administration to include legal education, which can improve the academic programmes of economics students by opening a door to ethical issues as well. Studying law can help students to understand better that business decisions are expected to deepen the respect of human dignity, to contribute to social integrity and to the proliferation of solidarity. For the purposes of developing business as a profession, it is thus crucial to try to make business more legal, and thus more ethical (Bagley - Clarkson Power 2006).

Business decisions are, in a number of instances, in a need of being complemented by ethical considerations. This is because market players cannot be successful unless they are able to contribute to the process of strengthening the integrity of society, taking the considerations of others into account. Sound business structures are based on the balance of positions held by people with different, or even conflicting, interests. Assuming moral values helps people in finding recognition of the place they have obtained in a society.

Social actions are to be complemented by ethical considerations, and ethical judgments must in turn be supported by legal instruments. Tony Honoré argues that, in terms of rational cooperative morality, the implementation of moral values into the every-day life must have determinants, such as calculations, conventions and commands (Honoré 1993: 11). Ethical reasoning and calculation of the performance of ethical rights and duties are to be made more exact by means of legal techniques. Conventions must be made more precise by statutory laws in many instances. Commands negotiating force are insufficient unless they are supported by legal prescriptions.

Law relies on the same traditions as morals. It is a peculiar advantage of law that it negotiates values within a hierarchical system of provisions, the meaning of which is determined, depending on the place they occupy in the very system. Legal rules appear in a well-ordered system of professional logic, relying on a series of formal institutions of coercion, supported by the centralised political power. Social conventions are mainly covered by ethical standards, which appear in legal 
norms as well. As long as they are part of the complex regulatory systems applicable to particular communities (e.g. those of business associations, civil movements, organisations of the safeguarding of interests, lobby groups, etc.), they can benefit from the high level of regularity and proficiency in formulating norms achieved in a legal system. From the perspective of these normative issues, the pedagogic side of ethics can be enhanced. For Tony Honoré, a "picture of morality as a blueprint and law as a structure put up either according to or in disregard of it is then seen to be misleading." It follows that in a complex society, a viable morality necessarily has a legal component (Honoré 1993: 3).

To illustrate the significance of law in improving ethics, the subject-matter of taxation can be mentioned. Taxation is not workable in a world where people pay taxes just because they are obliged by law to do that. The performance of their liability to pay tax should be completed by their conviction that taxes must be paid according to the ability-to-pay and that the payment of taxes enables their community to finance otherwise incontestable public functions. Taxation, furthermore, contributes to consolidating social life. There exists something in a society that is more fundamental than legal obligations. Citizens have to share the basic values of society, the respect of which cannot be secured just by laws. The interrelationship between the moral and legal obligation of the payment of taxes does not mean only that the legal rules on taxation must be supported by ethics. This interrelatedness also suggests that the liability to pay tax must be expressed in clear terms of statutory law.

The ethical aspects are indispensable indeed. Taxation, for instance, cannot function without applying the technique of self-assessment. Voluntary compliance is, thus, crucial. Nevertheless, the basic framework of the liability to pay tax must be established on legal rules, which is not because one can fear that people will not comply otherwise with their obligations or that the public authorities would make an abuse of their right to impose taxes. This is mainly because important agreements of the liability to pay tax must be expressed in the clear terms of statutory law.

It is interesting here to recall a passage from Swift's Gulliver's Travels (Swift 1967: 234-235):

"I heard a very warm debate between two professors, about the most commodious and effectual ways and means of raising money without grieving the subject. The first affirmed the justest method would be to lay a certain tax upon vices and folly, and the sum fixed upon every man to be rated after the fairest manner by a jury of his neighbours. The second was of an opinion directly contrary, to tax those qualities of body and mind for which men chiefly value themselves, the rate to be more or less, according to the degree of excelling, the decision whereof should be left entirely to their own breast. The highest tax was upon men who are the greatest favourites of the other sex, and the assessments according to the number and natures of the favours they have received; for which they are allowed to be their own vouch- 
ers. Wit, valour and politeness are likewise proposed to be largely taxed, and collected in the same manner, by every person's giving his own word for the quantum of what he possessed. But as to honour, justice, wisdom and learning, they should not be taxed at all, because they are qualifications of so singular a kind, that no man will either allow them in his neighbour, or value them in himself. The women were proposed to be taxed according to their beauty and skill in dressing, wherein they had the same privilege with the men, to be determined by their own judgement. But constancy, chastity, good sense, and good nature were not rated, because they would not bear the charge of collecting."

The best way is to make agreements in the parliament about the estimates on the ability-to-pay of different groups, taking the performance of the national economy into account. The result of this work is to legislate taxes.

The interplay between law and ethics presumes that not only business managers are expected to adopt ethical values, while taking their decisions. Lawyers are also required to be open to respect the rights, also those different from the offer of positive law. In other words, it is not only business managers, but also lawyers who must not be blind to ethical considerations, or rather to the solutions that constitute an alternative to the large mechanisms of the official society, secured by coercion and institutionalised and monopolised by the nation state.

Law does not go beyond the mere formalism and instrumentality unless it is designed to further human dignity. However, in the modernity produced in the development of the West, functional differentiation has been evolved, one of the consequences of which is that the regulative side of ethics has been emphasised, compared to the aretaic aspect (that is, to the virtues of ethics). Procedural justice has in this context emerged as an important factor. Bargaining is to promise actual and timely solutions from case to case. The rationality of positive law (as seen by Max Weber or Kelsen) has been completed by the skills, sensibility and intuitions of an artist. The ready-made solutions of positive law have lost their relevance in many areas of the social life.

To date, the institutions of formal social regulation are all the more frequently completed by alternative mechanisms that are based on self-regulation, or even self-generation of law. In the latter case, communities can develop with their own conventions, rules and standards that are generated and sanctioned within the boundaries of the communities themselves. From a micro perspective of local communities (like civil movements formed to protect the environment, improve media, do positive discrimination in favour of the disabled, etc.), regulatory systems can be developed, based on the coherence of the rules created by themselves. This coherence is timely and changeable if necessary. It is then of less importance whether the rules governing the life of these communities can be considered legal or ethical rules, or just the standards of the social practice followed under certain conditions. 
The coherence developed in local communities is fragile. The efficiency of the rules applicable to them depends on whether the macro environment is willing to tolerate (or even support) the operation of micro developments. Unfortunately, the macro relations of a society can be far from encouraging the development of flourishing communities for a number of reasons. One can mention the rule of poverty and deprivation, the lack of democracy, and serious inequality and inequity, among others.

\section{CONCLUSIONS}

The management of businesses is under-regulated. Strong arguments suggest that it must not remain so. Business must not consist purely of the bargaining of contracting parties engaged in zero-sum games. Instead, it should be pursued with regard to reconciling the interests of all contracting parties. Regulation may be established on professional standards, so that business management can become a profession.

Professions are studied as a subject-matter of the sociology of knowledge. As such, it is thus far from both economics and ethics. Nevertheless, where business administration and management are becoming a profession, ethical considerations may quickly come to fore. The management of businesses can arguably be considered as a subject that suits for being studied as a would-be profession.

This paper seeks to explore the major conditions for the development of business management into a profession. Currently, management is far from being recognised as one, the main reason for which is that there has not been consensus even concerning the contents of management activities, a subject of rudimentary nature. This writing suggests that a professional spirit be developed which could function as a filter of commercial reasoning.

For converting business management into a profession, it is not enough just to entertain courtesy, benevolence and affection. It is the cognitive condition for the development of business management as a profession that economics must be accompanied by the formalisation and systematisation of managerial sciences on a level necessary for reaching professional standards. Broadly, management will not be organised within the framework of a well-established profession unless formal knowledge, licensing, professional autonomy and professional codes of conduct are developed sufficiently.

In developing business as a profession, law may play a key role. Legal rules are able to negotiate businesses ethical values, which can be helpful for businesses in putting their decisions in a social context. It is crucial in the development of the 
master programmes of business administration to include legal education in their curricula.

Broadly speaking, the inclusion of more legal regulation can help businesses in understanding their stakeholders better. Companies may believe to be successful in the long run, provided that they are able to integrate themselves into the social environment in which they operate. It is not so much obvious that ethics cannot survive without legal regulation. Ethical calculations, conventions and commands cannot be negotiated unless they are associated with

- legal reasoning and the interpretation of the principles like legal certainty and due process;

- more precision and consistency to be provided by statutory law; and

- the judiciary enforcement of rights and a variety of alternative dispute resolutions.

Where the idea is that business management should be more professionalised, managers must first show that they are willing to adopt ethical values while arriving at business decisions. It is a peculiar chance for them to meet both ethical and legal values where ethics and the less formal requirements of social conduct are complemented by legal arguments. It is the other side of the coin that ethics cannot be supported by law unless lawyers are open to the means of generating and applying law, which are out of the scope of the close systems of positive law. Law and ethics, however, can support each other where social players are involved in discourse and find out what the conventions are and what the proper law is, applicable to specific cases. Law is surely not able to assist businesses in their ethical orientation where there is a Chinese wall between the official society and moralities. Hence, lawyers should be more sensible to adopt, elaborate and digest the non-legal environment.

Certainly, the mechanic application of legal rules will not help companies to become more ethical. In order to benefit from law, it is not enough that business managers adopt more ethics in their decision-making. Even the legal industry itself must, thus, be changed to enable itself for cooperation with non-lawyers and help company stakeholders to comprehend the interplay between business, law and ethics.

\section{REFERENCES}

ABA Model Code of Professional Responsibility, adopted by the American Bar Association on 12 August 1969 (and amended several times).

Society and Economy 31 (2009) 
Bagley, C. E. - Clarkson, G. - Power, R. (2006): Deep Links: Business School Students' Perceptions of the Role of Law and Ethics in Business. Harvard Business School, Working Paper No. 06-039.

Brandeis, L. D. (1912): Business - a profession (An address delivered at Brown University Commencement Day, 1912). System (October 1912).

Buber, M. (1995): Ich und Du. Stuttgart: Philipp Reclam.

Charter of Core Principles of the European Legal Profession and Code of Conduct for European Lawyers. Brussels: CCBE, 2008.

Freidson, E. (1986): Knowledge and the Practice of Sociology. Sociological Forum 1(4): 684-700.

Ghoshal, S. (2005): Bad Management Theories are Destroying Good Management Practices. Academy of Management, Learning \& Education 4(1): 75-91.

Gulick, L. (1937): Notes on the Theory of Organisation with Special Reference to Government in the United States. In: Gulick, L. - Urwick, L. (eds): Papers on the Science of Administration, New York: Institute of Public Administration.

Hayek, F. A. (1974): The Pretence of Knowledge. Lecture to the Memory of Alfred Nobel (December 11, 1974).

Honoré, A. M. (1993): The Dependence of Morality on Law. Oxford Journal of Legal Studies 13(1): $1-17$.

International Code of Ethics, first adopted in 1956. London: International Bar Association, 2008 edition.

Kasher, A. (2005): Professional Ethics and Collective Professional Autonomy: A Conceptual Analysis. Ethical Perspectives 11(1): 67-98.

Khurana, R. - Nohria, N. (2008): It's Time to Make Management a True Profession. Harvard Business Review (October): 70-77.

Khurana, R. - Nohria, N. - Penrice, D. (2005): Is Business Management a Profession? Harvard Business School Working Knowledge (21 February 2005).

Schön, D. (1983): The Reflective Practitioner. How Professionals Think in Action. London: Temple Smith.

Swift, J. (1967): Gulliver's Travels (Ed. by P. Dixon and J. Chalker). London: Penguin, Part III, Chap. 6.

Willmann, O. (1907): The Seven Liberal Arts. In: The Catholic Encyclopedia. New York: Robert Appleton Company (retrieved on 9 February 2009 from New Advent: http://www.newadvent.org/cathen/01760a.htm).

\section{NOTE}

1 The following sources of law can be instructive here:

- Council Directive 77/249/EEC of 22 March 1977 to facilitate the effective exercise by lawyers of freedom to provide services (1977, OJ L 78, p. 17);

- Directive 98/5/EC of the European Parliament and of the Council of 16 February 1998 to facilitate practice of the profession of lawyer on a permanent basis in a Member State other than that in which the qualification was obtained (1998, OJ L 77, p. 36);

- Case 2/74 Reyners v Belgian State [1974] ECR 631;

- Case 107/83 Ordre des avocats au barreau des Paris v Klopp [1984] ECR 2971;

- Case 292/86 Gullung v Councils de l'ordre des avocats du barreau de Colmar and de Saverne [1988] ERC 111; and

- C-309/99 Wouters and others [2002] ECR I-1577. 
